\title{
Innovation of Learning Device and Learning Media of Web- Based Nias Dance Techniques in Students of Dance Education Program of Art and Language Faculty in State University Of Medan (UNIMED)
}

\author{
Tuti Rahayu ${ }^{1}$, Sitti Rahmah ${ }^{2}$ \\ ${ }^{1,2}$ Universitas Negeri Medan, Indonesia \\ tutirahayu12@gmail.com
}

\begin{abstract}
Nias Dance Technique is one of the subjects included in the Presentation group, but the learning belongs to the education group. The aim is to innovate learning tools and web-based instructional media on Nias dance technique for students of Dance Program of Art and Language Faculty in State University of Medan. The type of research used is research and development $(R \& D)$. $R \& D$ is a research method used to produce certain products, and test the effectiveness of these products. The results of this study are that the Learning Tools and instructional media are to facilitate students in learning Nias Dance through web schology in the Department of Sendratasik. Learning device innovation consists of KKNI curriculum starting from RPS, LK, Assessment Rubric, Teaching Materials, VCD with dance material No Tatema Mbola.
\end{abstract}

Keywords: Learning innovation; national dance technique; no tatema mbola dance.

\section{Introduction}

Education is not merely knowledge about the curriculum or methodology of teaching alone. But how to this curriculum can run well in accordance with doing methodology. One component of the education system is the curriculum, because the curriculum is an educational component that is used as a reference by the organizers, especially by lecturers and leaders because the curriculum as a reference must be able to develop to keep pace with the changing times. In the past few years, there have been several changes to the educational curriculum, merely aimed at adjusting to the development of the times. Substitution is as a form of innovation in the curriculum, so that the substance of the related substance has improved quality better than before. According to Law No.11 of 1989 concerning the national education system, the curriculum is a set of plans and arrangements regarding the content and subject matter as well as the methods used as guidelines for organizing teaching and learning activities.

Curriculum and learning are intended as an idea, an idea or a particular action in the field of curriculum and learning that is considered new to solve educational problems. The problems of curriculum innovation are related to the principle of relevance between learning materials and the needs of students, between the quality of learning with users of graduates in the field of work, etc. Relating is to the quality of cognitive, affective, and psychomotor, while the equity is related in opportunities, then efficiency in terms of internal and external.

\section{Review of Literature}

Learning curriculum related to learning using the media. One of them to achieve learning is through the media. Media originating from Latin is a plural form of Medium which literally means an intermediary or introduction, that is, an intermediary or introduction 
to the source of the message with the recipient of the message. Scramm (1977) suggested that learning media is a messenger technology that can be utilized for learning purposes. Hamid (2014) states that learning media are a component of delivery strategies that can be loaded with messages that will be conveyed to students, whether they are people, tools or materials. Briggs (1997) suggests that learning media includes all the resources needed to carry out communication with students, this can be in the form of hardware such as computers, televisions, projectors and software used in hardware.

Based on the understanding of various sources about the media, learning media can be understood as one that can convey from a source in a planned manner so that a conducive learning environment occurs where the recipient can be done with the process effectively and efficiently. This learning media is filled with Nias Dance Engineering courses which will later be displayed on a website which will first be uploaded to the Internet network. This is an alternative by implementing the KKNI curriculum learning tool in Nias Dance Engineering course. Learning material is the core of the curriculum that serves as a means of achieving goals in the learning process. Learning materials in the learning process occupy an important position in the learning process, it is because teaching materials are material that will be delivered/ presented. Without teaching materials it is impossible for learning to be realized. Teaching materials must be in accordance with the expected goals and competencies in order to achieve the expected learning.

One of the reasons why this learning is displayed or uploaded via the web is to improve the ability of students to implement KKNI curriculum in Nias Dance Engineering course. So students can improve their technological understanding abilities and creative power that can be channeled with critical and innovative thinking skills. This student understanding is to improve the needs and resistance in learning. In this issue will reveal about matters relating to thoughts about the educational construct of a character and culture. The thinking of Jagondzin skiing (1994) in developing and disseminating knowledge that can assist students in pursuing three core functions of education:

- Facilitating student learning,

- Encourage student personal development.

- Promoting pro-social attitudes, habits, and behavior in students.

Three of these functions can help lecturers to realize the objectives of education to provide important insights to the students to develop learning, creative in thinking critical power. Currently the world of education is increasingly advancing with the emergence of educational technology products that support the learning process in schools. One of them is Electronic Learning (E-Learning). According to E-Lerning expert, William Horton (2003) in his book Technology and Tools for E-Lerning defines E-Lerning is as any use or use of internet and web technology to create learning experiences. It can be simplified into all forms of internet-based technology utilization to support the learning process, such as at school.

E-Lerningbased learning has several types. Among of them are independent learning based on E-Lerning, conventional learning based on E-Lerning, combination learning based on E-learning, fast response e-learning, and training guidance based on E-learning. The kinds of E-Lerning has a role is very important for student learning. Students and lecturers understand technology. The level of saturation in learning can also be suppressed. The result is certainly more effective and efficient as a supporter of the learning process, without reducing the role of the lecturer in guiding students directly. 
Learning with the media through technology whose dance material is No Tatema Mbola in Nias Engineering course will significantly stimulate student intelligence, when dancing activities are designed based on Developmentally Appropriate Practice (Gestwicki, 2007). When learning through dance is designed with attention to the development and creative needs of students in an atmosphere that is active, creative, effective, and fun, learning to dance will be meaningful in developing students' intelligence at school.

Research carried out is research and development (R\&D). R\&D is a research method used to produce certain products, and test the effectiveness of these products. The results of the study are products of learning tools consisting of KKNI curriculum starting from RPS, LK, Assessment Rubric, Teaching Materials, VCD with dance material No Tatema Mbola .

Active learning as an innovation in the curriculum and learning can optimize the use of all the potential possessed by students, so that all students can achieve satisfying learning outcomes in accordance with the personal characteristics they have. In addition active learning (active learning ) is also intended to maintain the attention of students / students to remain focused on the learning process. In learning with Active learning (active learning) empowerment of the left and right brain is very important. Thorndike (Ben Wagito, 1997) stated that 3 laws of study, namely 1); law of readiness is one's readiness to act can smooth the relationship between stimulus and response.2); law of exercise, i.e. with repeated tests, the relationship between stimulus and response will be smooth. 3); law of effect, namely the relationship between stimulus and response will be better if it can cause things that are fun, and this tends to always be repeated.

Active learning (active learning) basically seeks to strengthen and facilitate the stimulus and response of students in learning, so that the learning process becomes a fun thing, not a boring thing for them. By providing active learning strategies for students can help their memory, so they can be delivered to the learning objectives successfully. This is not considered in conventional learning. In the active learning method (active learning) each new subject matter must be linked to a variety of existing knowledge and experience. New subject matter is actively provided with existing knowledge. In order for students to learn actively, teachers need to create appropriate strategies in such a way that students have high motivation to learn. (Mulyasa, 2004).

\section{Discussion}

\subsection{Factors That Influence Innovation in Learning}

Innovations in the form of methods can have an impact in improvement. To improve the quality of learning and as a tool or new way to solve problems encountered in educational activities. Thus new methods or new ways of implementing existing methods such as in the learning process can be an effort to increase the effectiveness of learning. Meanwhile innovation in technology also needs to be considered given the many technological results that can be used to improve the quality of education, such as its use for learning technology, supervision procedures and management of educational information that can improve the efficiency of education implementation. The factors that influence educational innovation, namely:

\section{a. Lecturer}

Lecturers as the spearhead in implementing education in Higher Education are very influential parties in the teaching and learning process. The expertise and authority of a 
lecturer largely determines the continuity of the teaching and learning process in the classroom and its effects outside the classroom. Lecturers must be able to bring students to the goals to be achieved. There are several things that can establish the authority of the lecturers include mastery of the material being taught, teaching methods appropriate to the situation and condition of all- students, the relationship between the individual, both with students and among fellow lecturers and other elements that are involved in the educational process as administration, for example the head of study program and administration as well as the surrounding community, the experience and skills of the lecturer himself.

Thus, in the renewal of educational learning, the involvement of lecturers starting from the planning of learning innovations to the implementation and evaluation plays a very large role for the success of learning innovations. Without involving them, it is very likely they will reject the innovations introduced to them. This is as explained previously, because they consider innovations that do not involve them are not their own that must be implemented, but instead they assume will disturb the calm and smoothness of their tasks. Therefore, in a learning innovation, lecturers are the first and most involved because lecturers have broad roles as educators, as parents, as friends, as motivators and so on. (Wright, 1987) .

\section{b. Students}

As main object in the learning process, the students hold a very dominant role. In the process of teaching and learning, all- students can determine the success of learning through the use of intelligence, motor power, experience, willingness and commitment that arise in them without coercion. This can occur when the all- students are also involved in the process of innovation in learning to introduce to them the purpose of the change was from planning to implementation, so that what they do is a collective responsibility that must be carried out with the student of consequence. The rule of students to innovate education is more important than the role of other elements, because students is as recipients of the lesson, giving subject matter to their peers, guides, and even as lecturers. Therefore, to introduce the learning innovation to the application, the students need to be invited or to be involved so they do not just accept and implement these innovations, but also reduces the resistance as described previously.

\section{c. Curriculum}

The education curriculum, the narrower the curriculum also includes the teaching program and its tools are guidelines in the implementation of education and teaching in tertiary institutions. Because the curriculum is regarded as inseparable part in the process learning to implement this innovation learning, curriculum plays a role similar to other elements in education. Without a curriculum and without following the programs in it, educational innovation will not run in accordance with the goals of innovation itself.

Therefore, in upgrading education, those changes should be in accordance with changes in the curriculum or curriculum changes followed by the educational reform and possibly a change of both should be run in line with other elements in education. Without a curriculum and without following the programs in it, this learning innovation will not run in accordance with the goals of innovation itself. Therefore, in the discussion of education, the change should be in accordance with curriculum changes or curriculum changes followed by educational reforms and it is not impossible that the changes of both will go in the same direction. 


\section{d. Facilities}

Facilities, including educational facilities and infrastructure, cannot be ignored in the education process especially in the teaching and learning process. In upgrading education should be good facilities to influence the survival of innovations that will be implemented. Without, the facility so there is no innovation in education then the implementation of educational innovation will not be determined well. The facilities of teaching and learning are an essential thing to make changes and upgrading education. Therefore, in implementing an educational innovation, facilities need to be considered. For example with the availability of buildings, benches, tables and so on.

\section{e. Social Scope of the Community}

In applying innovative learning, there are things that are not directly involved in these changes but it could have an impact, positive or negative, to upgrade an education. The community is directly or indirectly, intentionally or not, involved in education. Because what you want to do in education, It actually will change the community for the better, especially the community where the students come from. Without involving society surroundings, learning innovation in the education will be disturbed, even if the damage cannot be told or involved. Community involvement in this innovation will instead help innovators and implementers of innovation in implementing educational innovations.

\subsection{The Innovation in Learning of No Tatema Mbola Dance}

Learning through dance requires a process through providing opportunities to busy themselves full of fun and preoccupation with children to be creative. For students, creativity should be a preferred process, and not too fast to expect creative products that are meaningful and useful. If lecturers are too quick to demand creative products that meet certain quality standards, this will reduce the fun and preoccupation of children to be creative. In nature it raises the activity of dance is giving freedom to students to carry out various explorations in order to realize or express themselves creatively. Lecturer dance can help to stimulate the students to involve themselves in creative to helped temper $u$ to seek fun and exciting atmosphere.

Dance is a motion art that is included in the visual arts which can be enjoyed through the sense of sight. Dance learning aims to train motor sensory, train sensitivity and coordinate movements and sounds, interpret the experiences around them in motion and so on. Studying dance, is a means to recognize and preserve the types of dance that exist in the area. Dancing from the beginning is a collective art, because in the process and framework of its form the place is formed by various other art disciplines, and dance as an art form is not only as expression of motion, but has brought with it the value of a sense of rhythm that is able to provide a touch of aesthetic sense (Hidayat, 2005). The beauty of dance is not only the harmony of bodily movements in space accompanied by certain music, but all expressions must contain the purpose of dance that is performed, so that to assess something dance art is used three aspects of wiraga, wirama, and wirasa

\section{a. No Tatema Mbola Dance}

No Tatema Mbola can be interpreted as accepting betel, this dance is a social dance originating from the area of Nias, North Sumatra. This dance depicts the joy and joy of the young people of Nias in establishing cooperation, harmony, intimacy and a sense of cohesiveness between them. The thing is always been maintained by Nias people through the reception and giving of betel in social life as a symbol of the reception of incoming guests. 


\section{b. Dance can educate students through daily activities}

Education can develop natural intelligence of students. Daily activities with the environment that can make students blend into the surrounding environment. In dance learning activities, the method is a motivation that can be said to be the overall driving force in each individual. If the method of learning dance is fun, of course by itself forming ' long term learning' which raises the motivation to continue to find out, to continue to explore. Of course we must also pay attention to the talents of each individual's pleasure. And it cannot be generalized that all children must master the same dance movements because that is where a person's uniqueness (individual difference) is.

The power of thought and this power can help to develop intellectual intelligence quotient. The reason is that sports can be accessed by students' insights into a variety of knowledge, developing Emotional quotient for personal or groups. Making a group study makes students sharpen emotional until creating tolerance and empathy for other people, enjoying and familiar to do activity in the groups. Exploring a fun in movement made great student activity repeating tirelessly. If we do everything happily we are free from pressure and what we produce will be better. Thus is a having fun in dancing. We must stimulate the child's desire to explore, directing it without interfering, let students with a natural desire to learn and become independent. Every a great student and his group will learn in a personal activity and learn to understand according to the unique needs and abilities. Created joy because there creates a special environment, the child's freedom, responsibility, social development, and intellectual will be developed spontaneously. So, it calls as lifelong education.

Howard Gardner in De Porter, Bobbi, \& Mike Hernacki stated that, a person will learn with all his abilities if he likes what he learns and he will feel happy to be involved in it. When creating an active and meaningful learning situation for students (active learning). The students as learners are stimulated through learning activities in order to build their knowledge through active learning process that they do themselves.

Based on the foregoing, the intelligence of students is basically able to be optimized through dance education which includes physical for motion, perception, power of thought and creativity in terms of processing motion.

\section{Conclusion}

Learning innovation is something that is important and must be owned or done by lecturers. This is because learning will be more lively and meaningful. Various innovations are expected to provide the motivation to be creative for students to be more active. The strategies to implement the innovation learning are as follows: 1) Mastering learning theory, 2) Enrich understanding of learning methods, 3) Reviewing the material that has been taught, 4) Get to know the condition of the class and its students, 5) Make observations on previous learning, 6) Evaluation on previous learning, 7) Make improvements in previous learning.

Changing the concept of learning from conventional to E-Lerning should be related to learning strategies in academic development. Without the connection and development, the innovation will fail. If the developed learning innovation is successful, it is likely to make students and students increasingly improve their abilities, make students do interactive 
learning, make assignments more diverse and fast in completion, and can develop strategies in terms of strengthening and evaluation. However, changing the concept of learning like this is not an easy thing to implement. This is recognized by some lecturers who have difficulty in implementing e-learning, but students also experience obstacles, especially in using computers. This will result in the low learning progress achieved because learning with the concept of not face to face is not easy when compared to a learning system where students and educators can face to face directly. Innovation finally becomes something that must be tried to do.

\section{References}

Antonius Aditya Hartanto and Onno W. Purbo. (2002). E-Lerning berbasis PHP dan MySql. Jakarta: Elex Media Komputindo.

Brigg, J. L. (1997). Instuction Design: Principle and Aplication. New York: Educational Tecnology Publication Inc.

Daryanto. (2010). Media Pembelajaran, Peranannya Sangat Penting Dalam Mencapai Tujuan Pembelajaran. Yogyakarta. Gava Media.

Depdiknas (2006). Panduan Pengembangan Silabus Mata PelajaranSeni Budaya Sekolah Menengah Pertama, Direktorat Jendral Pendidikan Dasar dan Menengah Pendidikan Sekolah Menengah Pertama: Jakarta.

Departemen Pendidikan and Kebudayaan. (1993). Peranan Masyarakat dalam Penyelenggaraan Taman Kanak-Kanak. Jakarta: Depdikbud.

Dryden, Gordon and Jeannette Vos.(2000). Revolusi Cara Belajar Bagian. II Sekolah Masa Depan. Bandung: Kaifa.

Effendi, \& Zhuang. (2005).E- Learning Konsep dan Aplikasi. Yogyakarta: ANDI.

Frelberg, HJ. And Driscoll, A (1992). Universal Teaching Strategies. Boston: Allyn \& Bacon

Gerlach, V.S \& Ely, D.(1980). Teaching and Media A Systematic Approach. New Jersey: Prentice Hall

Hamid, Abdul. (2014). Teori Belajar dan Pembelajaran, Medan: Program postgraduate Universitas Negeri Medan.

Iskandar, 2010. Panduan Lengkap Internet. Yogyakarta: Andi Offset.

Januari Jagondzinski dan mark Bracher Editor (1994), Psikoanalisis, Pendidikan dan

Transformasi.

Jhonsen. (2004), Aplikasi-aplikasi untuk Web Master, Jakarta: Elex Media Komputindo.

Kamarga, H. (2002). Belajar sejarah melalui e-learning: Alternatif Mengakses Sumber Informasi Kesejarahan. Jakarta: Inti Media.

Keeton, M.T .(2004). Best Oneline Instructional Practices: Report of Phase I of an Ongoing Study, Journal of Asynchronous Learning. Networks, Vol.8, No.2, 2004.75100

Mardiaatmaja, B.S (1986). Tantangan Dunia Pendidikan . Kanisius : Yogyakarta.

Mashadi, Rizal, A.. Syaifruddin. (2006). Teknologi Informasidan Komunikasi untuk SMP/MTs kelas IX. Semarang: Aneka Ilmu

Onno W. Purbo and Aang Arif Wahyudi, (2001),Mengenal E-commerce, Jakarta: PTElex Media Komputindo.

Parson, Wayne. 2006. Public Policy: Pengantar Teori dan Praktik Analisis Kebijakan. Jakarta: Kencana

Pressman, Roger S. (2002), Rekayasa Perangkat Lunak, Yogyakarta: Andi. 
Rahayu, Tuti. (2015). Pendidikan Tari Sebagai Pemberi Identitas Dalam Upaya Mendorong Pengembangan Pribadi Siswa. Seminar Nasional Forum Asosiasi Prodi Pendidikan Seni Drama, Tari dan Musik. Medan: AP2SENI.

Rahayu, Tuti. (2017). The Paradise of North Nias Island, Medan, Indonesia. Pluralistic and Harmony Phenomenon of Life. Beau Bassin: LAP Lambert Academic Publishing.

Scramm, Wilbur. (1977). Big Media, Little Media, Tools and Tecnologies for Instruction.London:SagePublication.

Soerjono Soekanto.2006.Sosiologi Suatu Pengantar (Jakarta: Raja Grapindo Persada)

Supriadi, Dedi. (2004). Membangun Bangsa Melalui Pendidikan.Bandung: Rosdakarya.

Zyainuri, Z., \& Marpanaji, E. (2012). Penerapan E-Lerningmoodle untuk Pembelajaransiswa yang melaksanakan prakerin. Jurnal UNY, 425. Onlinehttp://journal.uny.ac.id/index. php/jpv/article/view/1046 [accessed at 20 ${ }^{\text {th }}$ March 2016] 